\title{
Usefulness of argyrophilic nucleolar organizer regions in detection of lung cells alterations after benzo[a]pyrene instillation ${ }^{1}$
}

\author{
Uso do AgNOR na detecção de alterações \\ das células do pulmão após o instilação de benzo[a]pireno
}

\author{
Baldomero Antonio Kato da Silva ${ }^{2}$, Iandara Schettert Silva ${ }^{3}$, Daniel Martins Pereira ${ }^{4}$, Ricardo Dutra Aydos ${ }^{5}$, Paulo de \\ Tarso Camillo de Carvalho ${ }^{6}$ \\ 1. Postgraduate Program in Health Sciences in the Central West Region - Federal University of Brasília (UnB) and Federal University of \\ Mato Grosso do Sul, (UFMS), Campo Grande, Brazil. \\ 2. Fellow Master degree in Postgraduate Program in Health Sciences in the Central West Region - UnB and UFMS, Brazil. \\ 3. PhD, Associate Professor of the Department of Veterinary, University for Development of the State and the Pantanal Region \\ (UNIDERP), Brazil. \\ 4. Fellow Master degree in Post Graduate of Health and Development in the Central West Region, UFMS, Brazil. \\ 5. PhD, Associate Professor of the Department of Surgery, UFMS, Brazil. \\ 6. PhD, Associate Professor of the Department of Physiotherapy, UNIDERP, Brazil
}

\begin{abstract}
Purpose: To verify the relationship between AgNOR expression and lung tissues changes of Wistar rats after pulmonary instillation of benzo[a]pyrene (B[a]P). Methods: Male Rattus norvegicus albinus, Wistar lineage were given a single intrapulmonary instillation of $\mathrm{B}[\mathrm{a}] \mathrm{P}$ at doses of 10 and $20 \mathrm{mg} / \mathrm{kg}$ in a volume of approximately $0,3 \mathrm{ml}$. After 7 and 21 days the rats were killed and the lung slices submitted to a histological technique of AgNOR. AgNOR dots were quantified and the result analyzed by statistical tests; $p \leq 0,05$ was considered significant. Results: The mean values of AgNOR dots for the experimental groups $10 / 7(1,51 \pm 0,86)$ and $10 / 21(1,84 \pm 0,13)$ were statistically different $(p=0,009)$. Among the groups $20 / 7$ $(1,63 \pm 0,11)$ and $20 / 21(2,48 \pm 0,28)$ was observed statistically significant difference $(p=0,003)$. Conclusion: The AgNOR technique can be useful in identification of cells changes induced by B[a]P.
\end{abstract}

Key words: Benzo[a]pyrene. Biological Markers. Nucleolus Organizer Regions.

\section{RESUMO}

Objetivo: Verificar a relação entre a expressão de AgNOR e alterações teciduais pulmonares em ratos Wistar após instilação pulmonar de benzo[a]pireno (B[a]P). Métodos: Rattus norvegicus albinus, linhagem Wistar machos foram submetidos à instilação pulmonar única de B[a]P em doses de 10 e $20 \mathrm{mg} / \mathrm{kg}$, em um volume aproximado de 0,3 ml. Os animais foram sacrificados após 7 e 21 dias e o tecido pulmonar submetido a técnica histológica de AgNOR. Os pontos AgNOR foram quantificados e os resultados analisados estatisticamente; foram considerados significantes os valores de $\mathrm{p} \leq 0,05$. Resultados: Os valores médios de pontos AgNOR no grupo experimental 10/7 $(1,51 \pm 0,86)$ e 10/21 $(1,84 \pm 0,13)$ foram estatisticamente significantes $(p=0,009)$. Entre os grupos 20/7 $(1,63 \pm 0,11)$ e 20/21 $(2,48 \pm 0,28)$ a diferença observada foi também considerada significante $(\mathrm{p}=0,003)$. Conclusão: A técnica de AgNOR pode ser útil na identificação de alterações celulares induzidas pelo $\mathrm{B}[\mathrm{a}] \mathrm{P}$.

Descritores: Benzo[a]pireno. Marcadores Biológicos. Região Organizadora do Nucléolo.

\section{Introduction}

Lung cancer is the major cause of cancer related mortalities in the Western world. In the United States an estimated 170.000 individuals will die from this deadly disease despite the best current treatment approaches ${ }^{1}$. In the study of cancer, the efficacy of new treatment ideas in various cell lines can be investigated ${ }^{2,3}$, and a animal model of tumor permits the evaluation in vivo of new chemotherapic drugs in the treatment of bronchogenic lung cancer ${ }^{4}$. Clinically evident lung cancers have clonal genetic changes involving mutations or expression abnormalities in multiple genes. If we can detect some of these genetics alterations in preneoplasic respiratory epithelial lesions before cancer develops, early intervention and chemoprevention in such high risk individuals could greatly increase survival rates ${ }^{5}$. Environmental air pollution and smoking habits are the main sources of inhalation exposure to carcinogenic agents such as polycyclic aromatic hydrocarbons (PAH) ${ }^{6}$. PAHs are currently recognized as one of major classes of environmental carcinogenic pollutants ${ }^{7}$. Benzo[a]pyrene $(\mathrm{B}[\mathrm{a}] \mathrm{P})$ is a member of PAH family, and is often used as a model compound for PAH toxicity studies and has been shown to be a potent lung carcinogen in animal models of lung cancer. The selective carcinogenesis of the lung 
following exposure to $\mathrm{B}[\mathrm{a}] \mathrm{P}$ may be a consequence of many biochemical factors, including those that affect absorption, metabolism, and DNA repair ${ }^{8}$. The pathogenesis of lung cancer involves the accumulation of multiple molecular abnormalities over a long period of time. The alterations can happen at the level of gene silencing through methylation, DNA sequence changes, DNA segment amplification or deletion or whole chromosome gains or losses. These changes occur early in normal-appearing tissues that do not have the characteristics of cancer cells ${ }^{9}$. Determining the prognosis for an individual patient with lung cancer is difficult, in part because of the marked clinical heterogeneity of patients with the disease. This variation in clinical presentation and potential progression are, in turn, due to the multiple potential manifestation of the primary tumor, of involved metastatic sites, and of paraneoplasic syndromes. Despite of the clinical manifestations of lung cancer, the prognosis for a population of patients with lung cancer is remarkably predictable ${ }^{10}$. The inability to decide on the presence or absence of malignant cells in cytologic specimens cast a difficult problem in clinical management ${ }^{11}$. Biological markers are studied in diverse primary neoplasms. However, few of them proved to be clinically valuable, and the role of biological markers in lung cancer remains unclear because only a small number of markers has been properly assessed ${ }^{12}$. Argyrophilic staining for nucleolar organizer regions (AgNOR) is a technique to detect the argyrophilia of nucleolar organizer regions (NOR)-related proteins ${ }^{11}$. NORs are segments of DNA coding ribosomal genes and are situated on the short arms of acrocentric chromosomes. They can be demonstrated in formalinfixed paraffin-embedded tissues by one-step silver staining, the resulting black dots being termed AgNORs $^{13}$. NORs identified by means of an AgNOR were shown to be of value in determining prognosis in malignant tumors. Due to its sharp optical contrast, AgNOR expression can be easily quantified by morphometric procedures, making it possible to obtain a numeric indicator of the proliferative activity of the cells under study ${ }^{14}$. The aim of this study is to verify the relationship between AgNOR expression and lung tissues changes of wistar rats after pulmonary instillation of benzo[a]pyrene.

\section{Methods}

Male Rattus norvegicus albinus, Wistar lineage 08 to 12 weeks of age were obtained from UFMS central bioterio. Animals were housed four per cage on hardwood chip bedding and were given food and purified tap water ad libitum. Rats were randomized into treatment groups and were quarantined for 2 weeks prior to treatment, during which time they were acclimatized to 12-h light-dark cicles. $\mathrm{B}[\mathrm{a}] \mathrm{P}$ was suspended in $0,9 \%$ saline solution to obtain 10 and $20 \mathrm{mg} / \mathrm{ml}$ concentrations. Rats were anesthetized with a mixture of ketamine and xilazine, positioned in supine and a thoracocentesis with a $13 \mathrm{X} 4,5$ needle was realized in left lung. Rats (four per group) were given a single intrapulmonary instillation of $\mathrm{B}[\mathrm{a}] \mathrm{P}$ at doses of 10 and $20 \mathrm{mg} / \mathrm{kg}$ in a volume of approximately $0,3 \mathrm{ml}$ using a $1-\mathrm{ml}$ sterile syringe that was attached to the needle. The animals were divided in four groups: 10/ 7 (10 mg of B[a]P, killed after 7days); 10/21 (10 mg of $\mathrm{B}$ [a]P, killed after 21 days); 20/7 (20 mg of B[a]P, killed after 7 days); 20/21 (20 mg of B[a]P, killed after 21 days). A group of 04 rats (control) were also instilled with saline solution. Until their sacrifice, all animals were maintained four per cage under controlled ambient conditions and with free access to food and water. Rats were killed by intraperithoneal infusion of lethal dose of sodium penthobarbital on days 7 and 21 after intrapulmonary instillation. Sections of $3 \mathrm{~mm}$, obtained from each paraffin block of the longitudinal cut of left lung were selected and stained by the one-step silver colloid method. The sections were dewaxed in xylene and rehydrated through decreasing concentration of ethanol to distilled water. The AgNOR solution was freshly prepared by dissolving gelatin at a concentration of $2 \mathrm{~g} / \mathrm{dl}$ aqueous formic acid. This solution was added to $50 \mathrm{~g} / \mathrm{dl}$ aqueous silver nitrate solution. This final solution was then immediately poured on to the slides, which were left in the dark at room temperature for $45 \mathrm{~min}$. The silver colloid was washed from the sections with distilled water and the sections were dehydrated through a graded series of ethanol to xylene ${ }^{13}$. The slices were examined by light microscopy at $1000 \mathrm{X}$ magnification and an oil-immersion lens. Statistical evaluation was performed using Analysis of Variance followed Dunnet's multiple comparison test for dose-response data. If applicable, Student's $t$ test was used for pairwise comparison. The difference was considered significant when pd"0,05. The statistical procedures were followed with the aid of Bioestat 3.0 statistical software. All experiments respected the international rules for animal experimentation.

\section{Results}

Black silver-stained dots for AgNOR were clearly identified in all slices of the experimental group. The AgNOR dots were identified as black points within the nuclei. Significant alteration wasn't observed in control group. There is a statistically significant difference among all the experimental groups ( $\mathrm{p}<0,001$; ANOVA).

Figure 1 shows the mean values (and standard deviation) of AgNOR values for the different days of the $10 / 7$ and 10/21 experimental groups. There is a statistically significant difference among the groups $(\mathrm{p}=0,009$; Student's $t$ test).

Figure 2 shows the mean values (and standard deviation) of AgNOR values for the different days of the 20/7 and 20/21 experimental groups. There is a statistically significant difference among the groups $(p=0,003) .10$ / 21 and 20/21 ( $p=0,006$; Student's $t$ test $)$. 


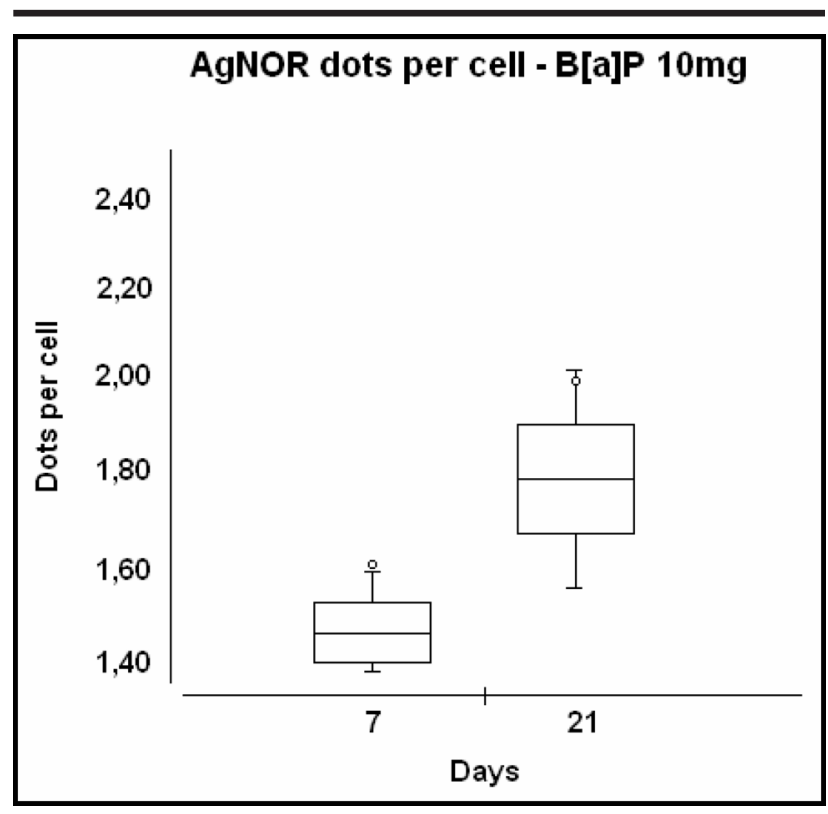

FIGURE 1 - Mean and standard deviation of 10/7 $(1,51 \pm 0,86)$ and 10/21 $(1,84 \pm 0,13)$ experimental groups.

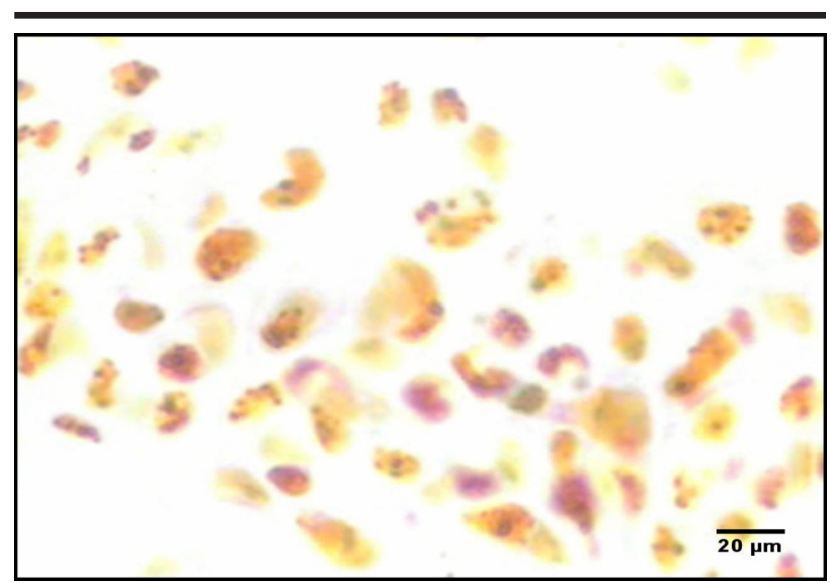

FIGURE 3 - Lung slice from an animal for the 20/21 experimental group. A cluster of cells showing silver-stained dots irregularly distributed and highly variable in size. (AgNOR method, original magnification X 1,000)

\section{Discussion}

The present study was designed to verify the expression of AgNOR in cellular aterations of wistar rats submmited to intrapulmonary instillation of B[a]P. Many studies have proved the value of morphometric evaluation of AgNOR in the differentiation of hyperplasia from incipient cellular alterations or in the detection of premalignant lesions of bronchial epithelium ${ }^{15,16}$. The AgNOR technique has been investigated in pulmonary pathology and cytology as a quantitative diagnostic aid and a marker of tumor proliferating capacity and prognosis ${ }^{11}$. Rocher et $a l^{17}$ found the expression of AgNOR such a important discriminator between benign and malignant cells in serous effusion. Kaneko et $a l^{18}$ demonstrated a positive correlation between AgNOR and survival of patients at stage I of non-small cell lung
AgNOR dots per cell - B[a]P 20mg

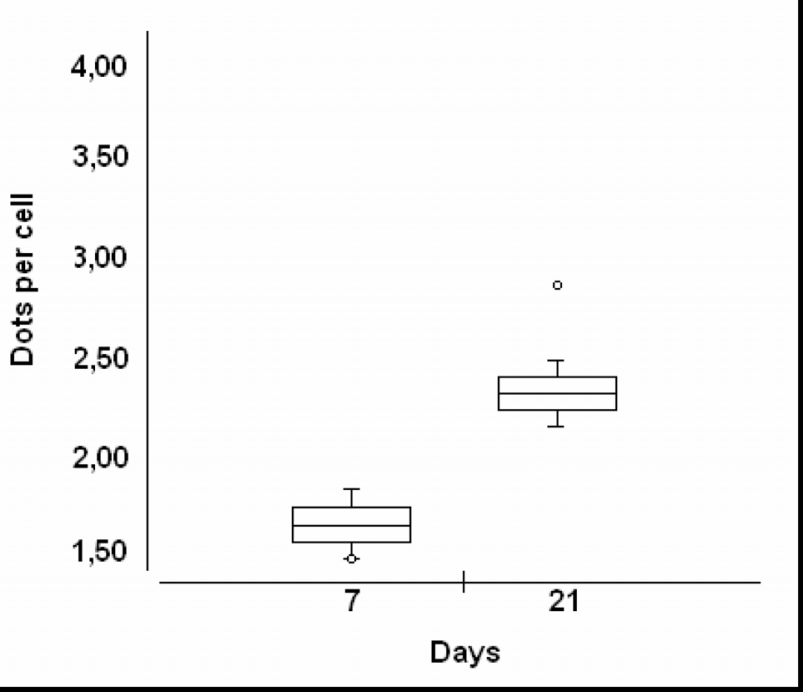

FIGURE 2 - Mean and standard deviation of 20/7 $(1,63 \pm 0,11)$ and 20/21 $(2,48 \pm 0,28)$ experimental groups.

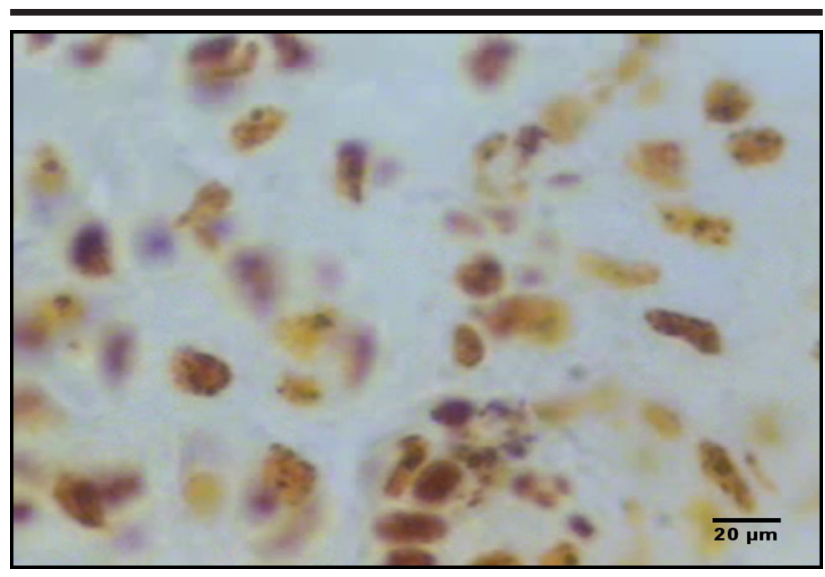

FIGURE 4 - Lung slice from an animal for the 10/21 experimental group. AgNOR dots are scarce and do not get into groups. (AgNOR method, original magnification X 1,000)

cancer. $\mathrm{B}[\mathrm{a}] \mathrm{P}$ has been used as a prototype carcinogenic polycyclic aromatic hydrocarbons since its isolation from coal tar in the 1930's. It produce a wide range of toxicities, including carcinogenicity in experimental animals, and acute inhalation induces squamous cell papillomas and carcinomas in the trachea ${ }^{19}$. Many studies have been reported animal $\mathrm{B}[\mathrm{a}] \mathrm{P}$ exposure by a single intratracheal instillation. However, in this study was performed intrapulmonary instillation of $\mathrm{B}[\mathrm{a}] \mathrm{P}$ by thoracocentesis, although inhalation is one of the primary routes of its exposure. The differences between AgNOR area per $\mathrm{mm}^{2}$ have been used in some studies as a method of quantify the number of malignant cells ${ }^{11}$. Rocher et al describe an average of 4,88 $\pm 1,5$ AgNOR particles for each reactive mesothelial cells ${ }^{17}$. The low amount of AgNOR spots observed in this study $(2,48 \pm 0,28$ per cell $)$ suggest underestimate exposition time of animals to $\mathrm{B}[\mathrm{a}] \mathrm{P}$. 


\section{Conclusion}

The AgNOR technique can be useful in identification of cells changes induced by B[a]P. Further studies will help clarify the real value of AgNOR technique in the pathogenesis identification of lung neoplasic diseases.

\section{References}

1. Duarte RLM, Paschoal MEM. Marcadores moleculares no câncer de pulmão: papel prognóstico e sua relação com o tabagismo. J Bras Pneumol. 2005;32(1):56-65.

2. Silva LFG, Soares FSD, Anselmo JNN, Fé DMM, Cavalcante JLBG, Moraes MO, Vasconcelos PRL. Modelo de tumor experimental em rim de ratos. Acta Cir Bras. 2002;17(1):62-6.

3. Lenox RJ. A model of human lung cancer. Chest. 2003;123(4):986-7.

4. Alves APNN, Guedes RC, Costa-Lotufo LV, Moraes MEA, Pessoa CO, Ferreira FVA, Moraes MO. Modelo experimental de tumor na cavidade oral de ratos com carcinossarcoma de Walker 256. Acta Cir Bras. 2004;19(4):406-14.

5. Forgacs E, Zöchbauer-Müller S, Oláh E, Minna JD. Molecular genetic abnormalities in the pathogenesis of human lung cancer. Pathol Oncol Res. 2001;7(1):6-13.

6. Agen B, Maas LM, Zwingmann IH, Schooten FJV, Kleinjans JCS. B[a]P adduct formation and induction of human epithelial lung cell transformation. Environ Mol Mutagen. 1997;30:287-92.

7. Wong DTW, Biswas DK. Mechanism of benzo(a)pyrene induction of alpha-human chorionic gonadotropin gene expression in human lung tumor cells. J Cell Biol. 1985;101:2245-52.

8. Harrigan JA, Vezina CM, McGarrigle BP, Ersing N, Box $\mathrm{HC}$, Maccubbin AE, Olson JR. DNA adduct formation in precision-cut rat liver and lung slices exposed to benzo[a]pyrene. Toxicol Sci. 2003;77:307-14.

9. Massion PP, Carbone DP. The molecular basis of lung cancer: molecular abnormalities and therapeutic implications. Resp Res. 2003; 4(12):1-15.
10. Brundage MD, Davies D, Mackillop WJ. Chest. 2002 ;122(3) :1037-57.

11. Chern JH, Lee YC, Yang MH, Chang SC, Perng RP. Usefulness of argyrophilic nucleolar organizer regions score to differentiate suspicious malignancy in pulmonary cytology. Chest. 1997;111(6):1591-6.

12. Capelozzi VL. Entendendo o papel de marcadores biológicos no câncer de pulmão. J Pneumol. 2001; 27(6):321-8.

13. Rodrigues, OR, Antonangelo L, Yagi N, Minamoto H, Schmidt AF, Capelozzi VL, Goldenberg S, Saldiva PHN. Prognostic significance of argyrophilic nucleolar organizer region (AgNOR) in resected non-small cell lung cancer (NSCLC). Jpn J Clin Oncol. 1997;27(5):298-304.

14. Antonangelo L, Bernardi FDC, Capelozzi VL, Takagaki TY, Younes RN, Yagi N, Saldiva PHN. Morphometric evaluation of argyrophilic nucleolar organizer region is useful in predicting long-term survival in squamous cell carcinoma of the lung. Chest. 1997;111:110-4.

15. Abe S, Ogura S, Kunikane H, Suko N, Watanabe N, Nakajima I. Nucleolar organizer regions in precancerous and cancerous lesions of the bronchus. Cancer. 1991;67:472-5.

16. Fisseler-Eckhoff A, Becker T, Sudhoff H, Muller KM. AgNOR counts in preneoplasic lesions of the bronchus. Pathol Res Pract. 1994;190:389-393.

17. Rocher AE, Blanco AM, Palaoro LA. Utilidad de la técnica de AgNOR en la interpretación de los derrames de cavidades serosas. Rev Med Chile. 2000;128:963-8.

18. Kaneko S, Ishida T, Sugio K, Yokoyama H, Sugimachi K. Nucleolar organizer regions as a prognostic indicator for stage I non-small cell lung cancer. Cancer Res. 1991;51:4008-11.

19. Kong LY, Luster MI, Dixon D, O’Grady J, Rosenthal GJ. Inhibition of lung immunity after intratracheal instillation of benzo(a)pyrene. Am J Resp Crit Care Med. 1994;150:1123-9.
Correspondence:

Baldomero Antonio Kato da Silva

Gardênia No. 129, Bl F, Apto. 202

Cidade Jardim

79040-570 - Campo Grande - MS - Brazil
Interest conflict: none Financing source: none

\section{How to cite this article:}

Silva BAK, Silva IS, Pereira DM, Aydos RD, Carvalho PTC. Usefulness of argyrophilic nucleolar organizer regions in detection of lung cells alterations after benzo[a]pyrene instillation. Acta Cir Bras. [serial on the Internet] $2006 ; 21$ Suppl 4. Available from URL: http://www.scielo.br/acb. 